\title{
Pyrroles as Privileged Scaffolds in the Search for New Potential HIV Inhibitors
}

\author{
Maria da Conceição Avelino Dias Bianco ${ }^{1,2}$, Debora Inacio Leite Firmino Marinho ${ }^{1}$, Lucas Villas Boas Hoelz ${ }^{1}$, \\ Monica Macedo Bastos ${ }^{1,2}$ and Nubia Boechat $1,2, *$
}

1 Laboratório de Sintese de Farmacos—LASFAR, Instituto de Tecnologia em Farmacos—Farmanguinhos, FIOCRUZ, Rua Sizenando Nabuco 100, Manguinhos, Rio de Janeiro 21041-250, RJ, Brazil; mariaconcz@hotmail.com (M.d.C.A.D.B.); debora.marinho@far.fiocruz.br (D.I.L.F.M.); lucas.hoelz@far.fiocruz.br (L.V.B.H.); monica.macedo@far.fiocruz.br (M.M.B.)

2 Centro de Ciencias da Saude-CCS, Programa de Pos-graduação em Farmacologia e Quimica Medicinal do Instituto de Ciencias Biomedicas-ICB-UFRJ, Bloco J, Ilha do Fundao, Rio de Janeiro 21941-902, RJ, Brazil

* Correspondence: nubia.boechat@far.fiocruz.br; Tel.: +55-21-39772465

Citation: Bianco, M.d.C.A.D.;

Marinho, D.I.L.F.; Hoelz, L.V.B.;

Bastos, M.M.; Boechat, N. Pyrroles as

Privileged Scaffolds in the Search for New Potential HIV Inhibitors.

Pharmaceuticals 2021, 14, 893. https://

doi.org/10.3390/ph14090893

Academic Editors: Antonella Messore and Mary J. Meegan

Received: 6 May 2021

Accepted: 24 August 2021

Published: 2 September 2021

Publisher's Note: MDPI stays neutral with regard to jurisdictional claims in published maps and institutional affiliations.

Copyright: (c) 2021 by the authors. Licensee MDPI, Basel, Switzerland. This article is an open access article distributed under the terms and conditions of the Creative Commons Attribution (CC BY) license (https:// creativecommons.org/licenses/by/ $4.0 /)$.

\begin{abstract}
Acquired immunodeficiency syndrome (AIDS) is caused by human immunodeficiency virus (HIV) and remains a global health problem four decades after the report of its first case. Despite success in viral load suppression and the increase in patient survival due to combined antiretroviral therapy (cART), the development of new drugs has become imperative due to strains that have become resistant to antiretrovirals. In this context, there has been a continuous search for new anti-HIV agents based on several chemical scaffolds, including nitrogenated heterocyclic pyrrole rings, which have been included in several compounds with antiretroviral activity. Thus, this review aims to describe pyrrole-based compounds with anti-HIV activity as a new potential treatment against AIDS, covering the period between 2015 and 2020. Our research allowed us to conclude that pyrrole derivatives are still worth exploring, as they may provide highly active compounds targeting different steps of the HIV-1 replication cycle and act with an innovative mechanism.
\end{abstract}

Keywords: pyrrole; heterocycle; AIDS; HIV; CD4 antagonist; glycoprotein; entry-inhibitors; reverse transcriptase; integrase

\section{Introduction}

Acquired immunodeficiency syndrome (AIDS) is caused by the human immunodeficiency virus (HIV) and remains a global health problem four decades after the report of its first case [1]. As of 2019, there were 38 million people living with HIV infection globally. Nonetheless, millions of lives have been saved through the combination of antiretroviral therapy (cART) access since 1996 [2].

cART, usually called an AIDS cocktail, is composed of more than one drug, and must be administered daily for the lifetime of the infected patient once HIV has been integrated into the host cell genome DNA. CD4+ Lymphocyte infection and destruction result in the severe immunosuppression features of AIDS, allowing the establishment of secondary infections [3,4]. The available anti-HIV drugs target the essential HIV enzymes reverse transcriptase (RT), integrase (IN), and protease. However, other stages of HIV infection can be addressed, for example, entry and capsid inhibitors $[5,6]$. There is no cure for this disease or a vaccine to help to avoid HIV transmission, and drug-based therapy is the only means to control infection progress [7].

Despite the success of viral load suppression and increased patient survival due to the correct administration of cART, the development of new drugs and formulations of combined fixed doses (CFDs), and long-releasing formulations with better patient adherence and tolerability to treatment, is imperative. These aspects are also essential for decreasing the selection of drug-resistant viral strains, which are currently one of the 
significant problems of therapy [6,8]. In addition, several drawbacks have been developed due to cART, including long-term toxicity and drug-drug interactions [9].

In this context, there has been a continuous search for new anti-HIV agents based on several chemical groups, including nitrogenated heterocycles such as pyrroles [8]. The application of heterocycles is a strategy that is widely used in medicinal chemistry to obtain drug candidates because it can modulate properties related to pharmacokinetics, such as solubility, lipophilicity, polarity, and pharmacodynamics, such as hydrogen-bonding capacity and the ability to form complexes with coordinating metals [10,11].

The pyrrole ring (Figure 1) is a five-membered aromatic heterocycle with electron-rich characteristics. It comprises four carbon atoms and was isolated and characterized for the first time in $1857[12,13]$. The pyrrole moiety is obtained through various synthetic methods widely discussed in the literature [14], besides being found extensively in natural products [11]. This heterocycle is commonly found in molecules with several biological activities, for example, in drugs approved by the Food and Drug Administration (FDA), such as the anticancer drug sunitinib (Figure 1). It is also possible to find this nucleus fused with other cycles in antiemetic, anti-inflammatory, and antiviral agents such as remdesivir (Figure 1) [10,14].

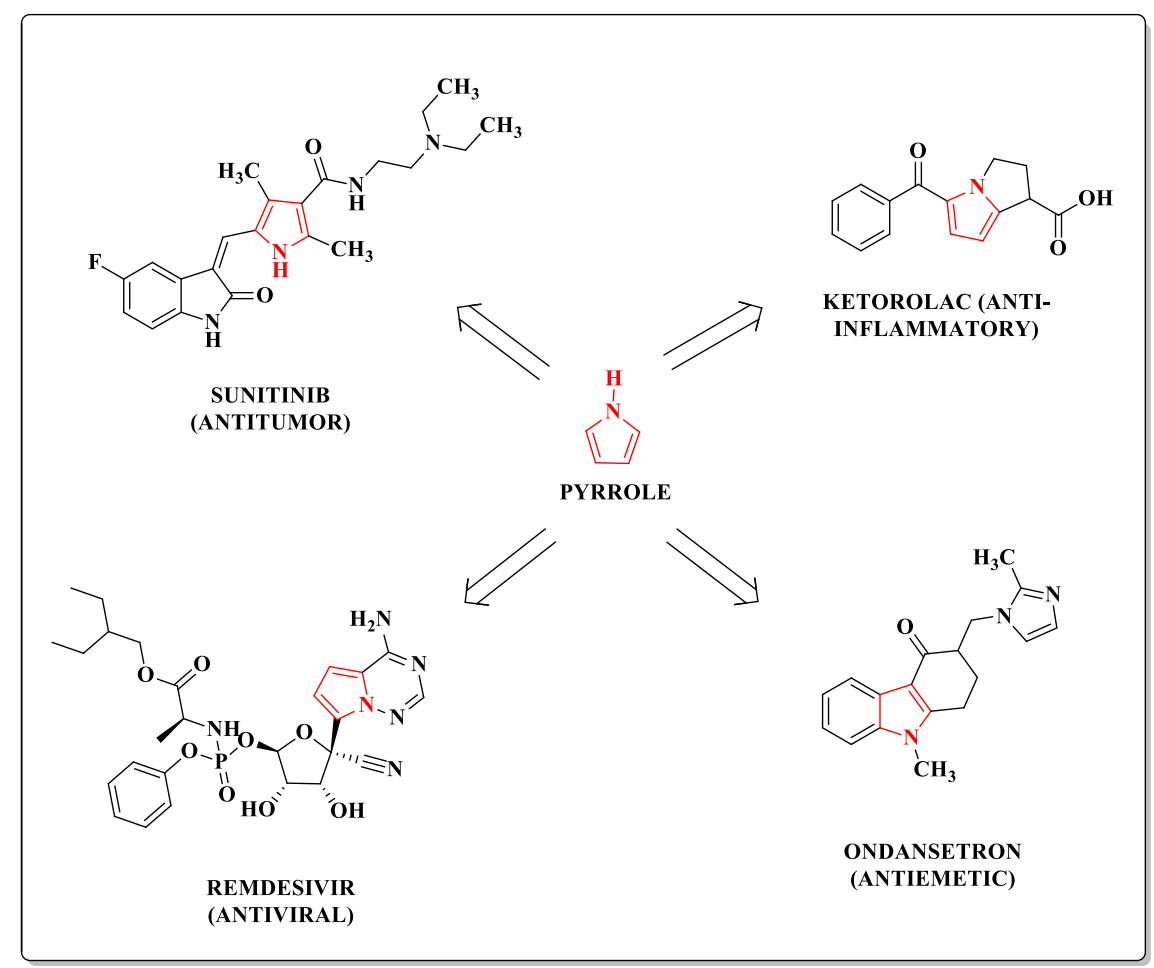

Figure 1. Examples of drugs containing pyrrole moieties approved by the FDA.

Researchers have summarized the applications of pyrrole as a privileged structure in the development of potential anti-HIV drug candidates [8,10,15-20], in particular targeting HIV-1 gp-120, RT, and IN. In this review, we provide an overview of pyrrole-based compounds with anti-HIV activity as possible future trends in the treatment of AIDS. We explored the literature between 2015 and 2020, selecting the most relevant papers that showed the importance of pyrroles and their structure-activity relationship (SAR) data as HIV inhibitors.

\section{Pyrrole-Based Entry Inhibitors of the HIV-1}

The beginning of the HIV replication cycle occurs through attachment between the CD4 cell receptor and the HIV surface envelope glycoprotein gp120. This event forces gp120 to change its conformation, facilitating binding to the host cell coreceptor CCR5 (in 
M-tropic viruses) or CXCR4 (in T-tropic viruses) in the V3 loop of gp120 [21]. The CD4 binding site of the HIV-1 gp120 envelope, termed the Phe43 cavity, is highly conserved and has been hypothesized to be a site less prone to resistance-conferring mutations [22]. The fusion step occurs with the assistance of gp41, which also undergoes a conformational change due to the interactions described earlier $[23,24]$.

Therefore, based on this initial infection process, the inhibitors that block the attachment or fusion process are collectively termed "entry inhibitors" and can act on the glycoproteins (gp120 and gp41), and receptors and coreceptors present on the host cell surface (CD4 and CCR5 or CXCR4). Maraviroc and enfuvirtide are currently available CCR5 and gp41 inhibitors, respectively [24,25].

Fostemsavir (Rukobia), a prodrug of temsavir (Figure 2), is an entry inhibitor that was most recently approved in the United States by the FDA in July 2020 and Europe by the European Medicine Agency (EMA) in the same year [26,27]. This drug binds directly to the gp120 subunit surface-accessible pocket at the interface between the inner and outer domains of gp120 under the $\beta 20-21$ loop interacting with the $C$ terminus of the $\alpha 1$ helix [28]. This interaction process blocks HIV from attaching to the CD4+ T cells of the host immune system and prevents the virus from infecting these cells and multiplying $[29,30]$. Temsavir has been described to act against CCR5-, CXCR4-, and dual-tropic (R5X4) strains of HIV-1 [31-35]. It is essential to mention that fostemsavir is the first antiretroviral drug that contains a pyrrolopyridine ring in its chemical structure (Figure 2).

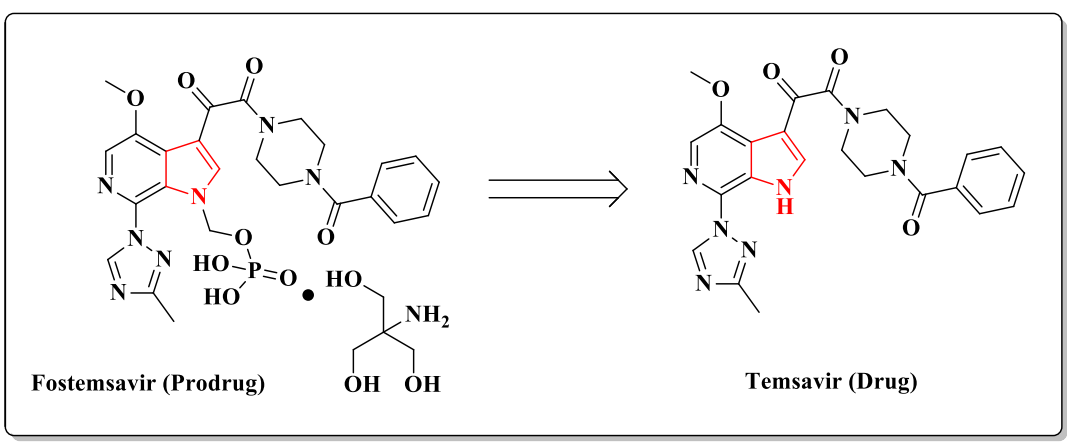

Figure 2. Chemical structures of temsavir and its prodrug fostemsavir, highlighting the pyrrole ring in red.

The introduction of a phosphate group at the $N$-position in the pyrrole ring allows fostemsavir to improve its solubility in the gut, facilitating efficient dissolution. Fostemsavir is converted to temsavir by alkaline phosphatase in the gastrointestinal lumen. Thus, the drug can rapidly be absorbed due to its efficient membrane permeability, and the NH group on the pyrrolopyridine ring is free to take part in the key interactions with the gp120 [36].

The crystal structure of the gp120-temsavir complex (PDB code: 5u7o) shows that temsavir binds to a surface-accessible cavity interface between the inner and outer domains of the glycoprotein under the $\beta 20-21$ loop, interacting with the $C$ terminus of the $\alpha 1$-helix (Figure 3A) [30]. According to Pancera and coworkers [30], temsavir interacts with gp120 mainly through steric interactions, including Ile108, Ile109, Trp112, Asp113, Leu116, Thr202, Val255, Ser256, Thr257, Glu370, Ser375, Phe376, Phe382, Phe383, Tyr384, Ile424, Asn425, Met426, Trp427, Asn428, Gln432, Ala433, Met434, and Met475 residues (Figure 3B,C). In addition, two hydrogen bonds are present in the temsavir-gp120 complex: one between the backbone NH of Trp427 and its oxoacetamide carbonyl, and the other between the side-chain carboxylate of Asp113 and the NH group of its pyrrolopyridine ring (Figure 3D). Other interactions include the benzoyl group of temsavir, which enables aromatic stacking with Phe382 and Trp427 of gp120 (Figure 3E). 


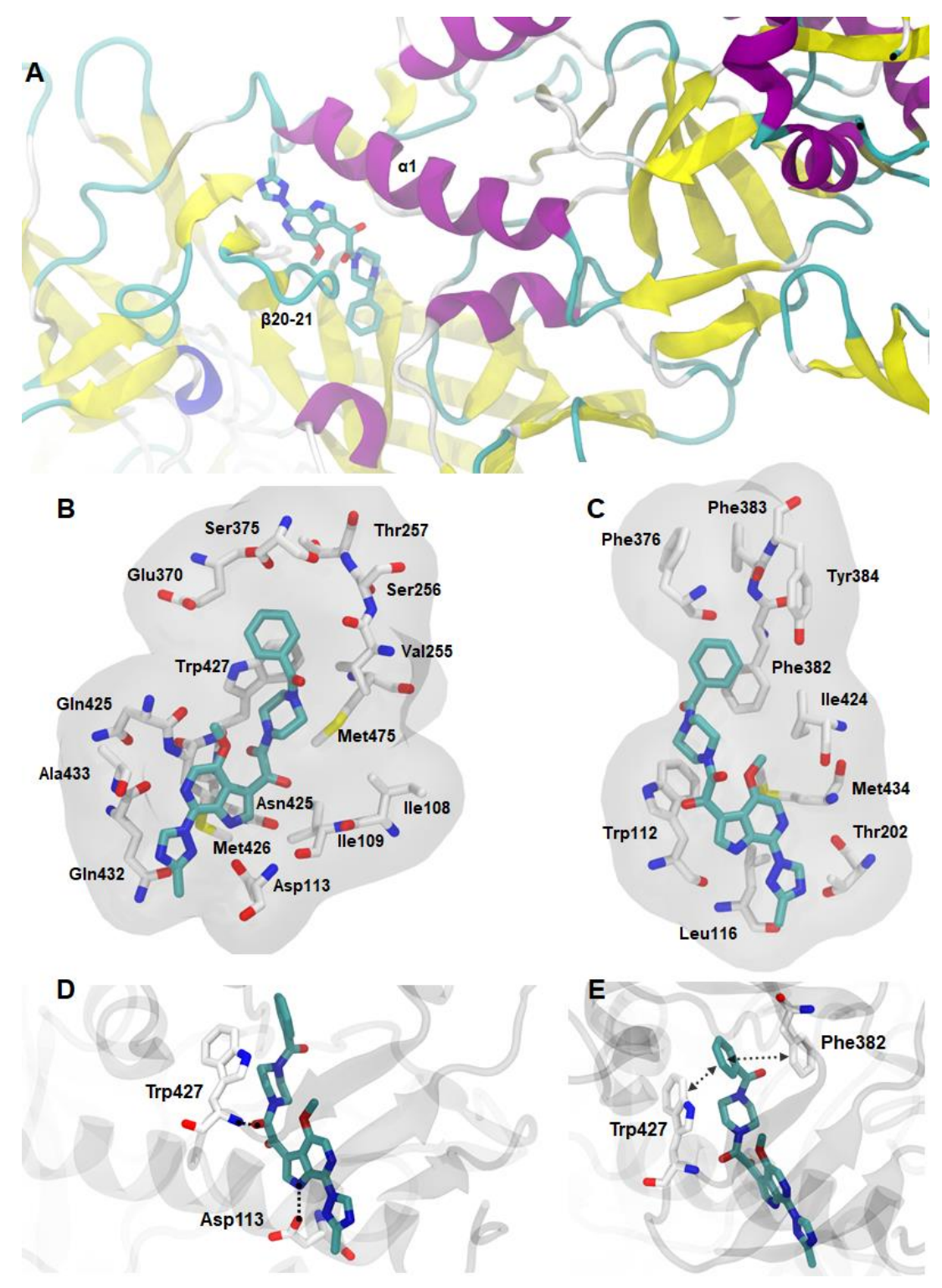

Figure 3. (A) Representations of the temsavir binding site into gp120, showing the $\beta 20-21$ loop ( $\beta 20-21)$ and $\alpha 1$-helix $(\alpha 1)$, and the interactions between temsavir and gp120: (B,C) steric, (D) hydrogen bond, and (E) aromatic-stacking interactions. The hydrogen bonds and aromatic-stacking interactions are represented by black interrupted lines. The gp120 protein is in cartoon representation, colored by secondary structure ( $\beta$-sheet in yellow, $\alpha$-helix in purple, turn in cyan, and random structure in white). Temsavir and gp120 residue structures are shown in the stick models and colored by atom (the nitrogen atoms are shown in blue, the oxygen atoms in red, the sulfur atoms in yellow, and the carbon chain in white or cyan).

Despite advances in the discovery and approval of new entry inhibitors, several research groups have been working to obtain molecules of this antiretroviral class [37-43]. One example was the discovery of NBD-11021 (1) (Figure 4) [37], which presented antagonistic entry properties for HIV-1 and was the precursor for the development of new derivatives with similar characteristics. The design of this molecule was based on changing the oxalamide in the precursor NBD-09027 (2) to a pyrrole ring (Figure 4). This change enabled the conversion of a compound that was a CD4 agonist and enhanced the entry of HIV-1 into the cell into a full CD4 antagonist (Figure 4). The pyrrole ring rigidity forces conformational changes, leading to the formation of a hydrogen bond between the piperidine ring and Asp368 in the cavity of gp120 [37]. Prototype 2 does not present this kind of 
interaction. However, the authors explain it is not possible to attribute the CD4 antagonism from this interaction due to the restricted $X$-ray structural information.

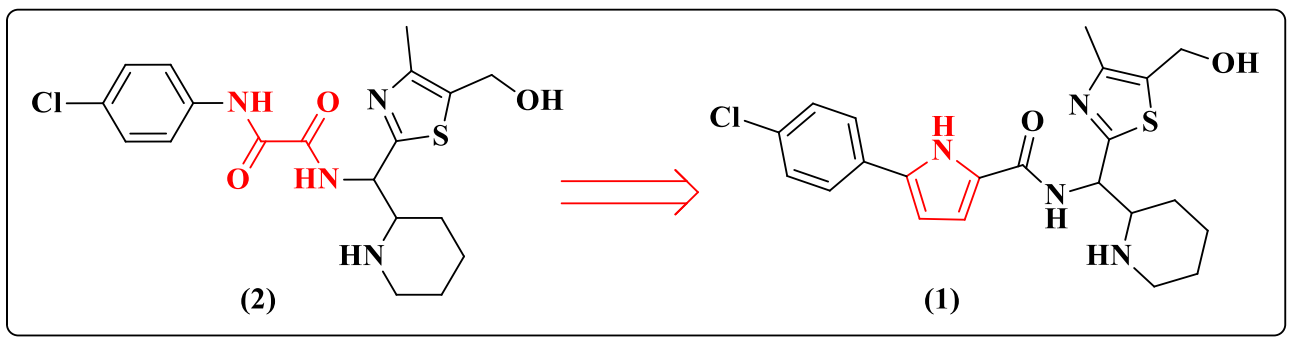

Figure 4. Chemical structure of compounds 1 and 2 [37].

Compound 1 yielded a diastereomeric mixture (four isomers), which authors designated "NBD-11021" and used in different assays [37].

Compound $\mathbf{1}$ was more active than $\mathbf{2}$ in both single- and multicycle assay (Table 1) [37]. Another important discovery was the capacity of 1 to inhibit both CCR5- and CXCR4-tropic HIV-1 with similar potency (IC 50 of $~ 1.7-2.4 \mu \mathrm{M}$ ) [37].

The gp120 crystal structure core in the complex with 1 indicates that a cumulative effect of the binding of this compound in the Phe 43 cavity in gp120, which is in the proximity of the V3 loop, may have altered the conformation of gp120 to be no longer suitable for CCR5 binding. Consequently, 1 behaves as a CD4 antagonist. Another exciting aspect is that isomer R/S-(1) (NBD-11021A2) inhibits RT, but at a much higher concentration ( $\mathrm{IC}_{50}$ of $43.4 \mu \mathrm{M})$ (Table 1) [37].

In 2016, Curreli and coworkers [38] synthesized twenty-five new analogues of $\mathbf{1}$. The X-ray structure of $\mathbf{1}$ with gp120 reported earlier confirmed that the piperidine ring benefited from enabling its nitrogen atom to hydrogen bond with Asp368 of gp120 [37]. All molecules were tested against HIV-1 in a single cycle and a multicycle infectivity assay. Among these, a substantial improvement in antiviral activity was observed in compounds in which the entire piperidine ring was replaced with a simple primary amine $\left(\mathrm{CH}_{2} \mathrm{NH}_{2}\right)$, such as compounds NBD-14009 (3) and NBD-14010 (4) (Figure 5). By replacing the piperidine ring with a methylamine group, the authors reduced solvent exposure of hydrophobic regions and retained the amine for a hydrogen bonding with Asp368 of gp120. They also focused on enhancing surface complementarity between the compound and the cavity $[44,45]$ by replacing the phenyl ring of $\mathbf{1}$, which accesses the Phe 43 cavity, with a meta-fluoro substituted phenyl ring, as seen in compound 4 (Figure 5) [38].

Compound $\mathbf{3}$ was equipotent to $\mathbf{1}$ in the single-cycle screening, but less active in the multicycle assay (Figure 5). By comparison, compound 4 proved to be more than two-fold more potent than the prototype in the single-cycle screening (Figure 5), and exhibited better potency than 1 in the multicycle testing (Figure 5). The crystal structure of 4 in complex with HIV-1 gp120 at 2.1 A resolution confirmed that the meta-fluoro substituted phenyl ring improved surface complementarity with the Phe 43 cavity [39]. Both analogs 3 and 4 are less cytotoxic than prototype $\mathbf{1}$ (Table 1 ).

In a continuing effort to discover other analogues of compounds $\mathbf{1}$ and 2, the Curreli group [39] designed sixty novel analogues with modifications to regions I and III of compound 1 (Figure 6). Among these, NBD-14088 (5) and NBD-14107 (6) (Figure 6) displayed excellent activities against HIV-1 (Figure 6). Improvements in the antiviral activity and selectivity index ( $\mathrm{SI} ; \mathrm{CC}_{50} / \mathrm{IC}_{50}$ ) values by $\sim 8$ - and 6 -fold in the first one-cycle assay were observed (Table 1). The ability of 5 and $\mathbf{6}$ to inhibit RT was also verified, and both compounds were shown to be more potent than 1 , showing $\mathrm{IC}_{50}$ values of $7.2 \mu \mathrm{M}$ (5) and $8.4 \mu \mathrm{M}(6)$ (Table 1) [39]. 


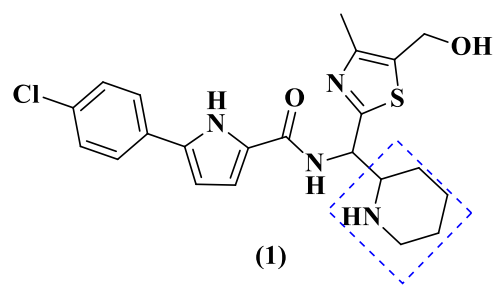

$$
\begin{aligned}
& \mathrm{IC}_{50} \text { of } 2.2 \mu \mathrm{M} \text { (single-cycle assay) } \\
& \mathrm{IC}_{50} \text { of } 0.85 \mu \mathrm{M} \text { (multicycle assay) }
\end{aligned}
$$

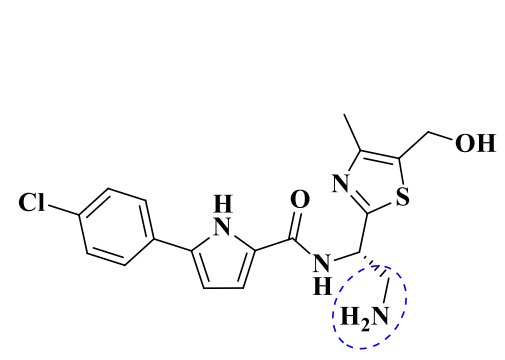

S-(3)

$\mathrm{IC}_{50}$ of $2.1 \mu \mathrm{M}$ (single-cycle assay)

IC $_{50}$ of $2.7 \mu \mathrm{M}$ (multicycle assay)<smiles></smiles>

Figure 5. Structures of $\mathbf{1}, \mathbf{3}$, and 4 and their anti-HIV-1 profiles [37,38].

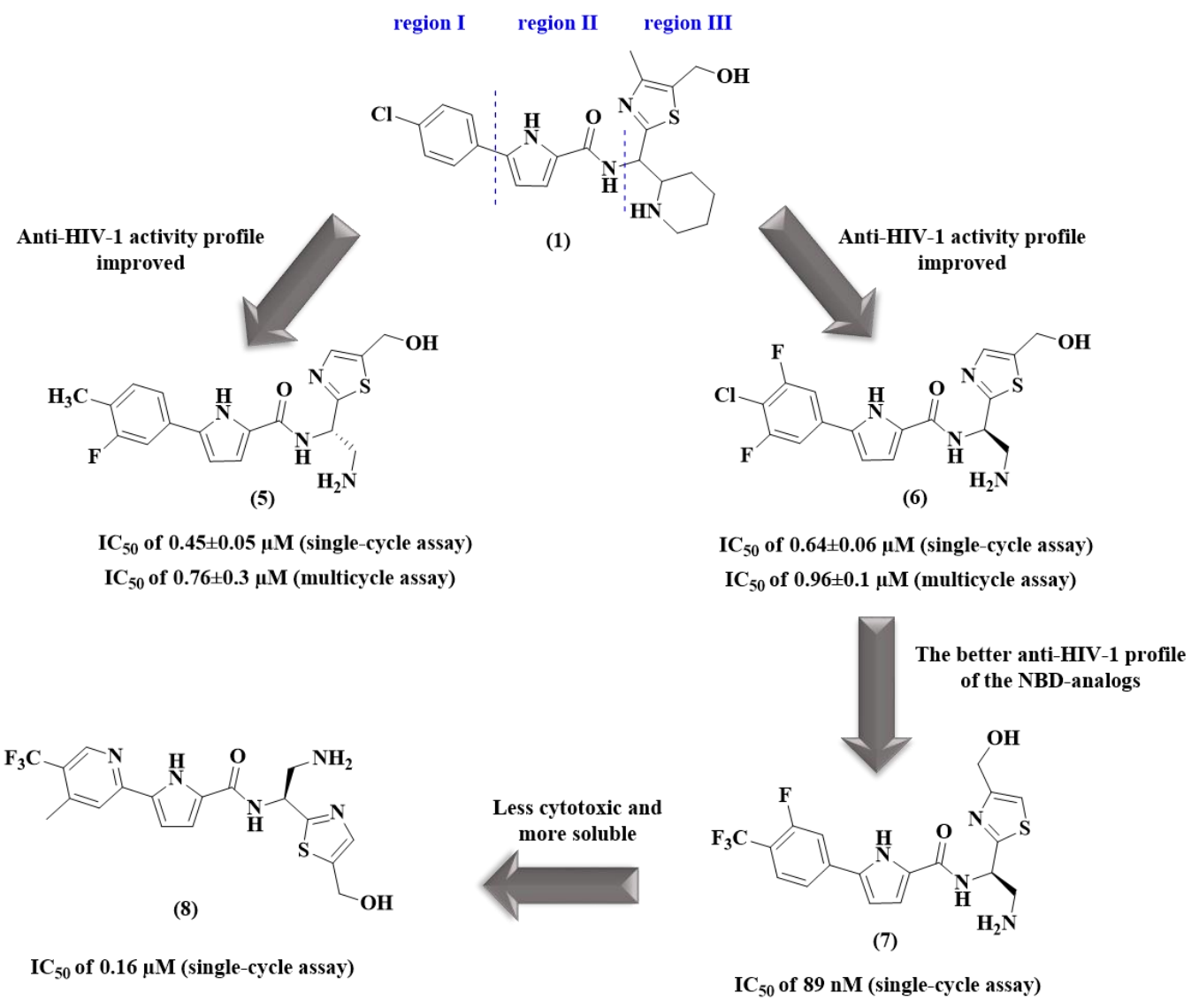

Figure 6. Structural modifications of compound 1 that led to analogs $\mathbf{5 - 8}$ and their anti-HIV-1 profiles [39-41].

Based on lead compound 6, Curreli et al. [40] designed a new series of twenty-nine compounds. Through an approach that can enhance interactions with gp120, a change in 
the $\mathrm{CH}_{2} \mathrm{OH}$ group from $\mathrm{C}-5$ to $\mathrm{C}-4$ in the thiazole moiety was proposed. This change of position was based on observations of the crystal structure of HIV-1 gp120 in complex with 4 that showed important information about the interaction profile $[39,40]$.

A notable improvement in antiviral activity was achieved with NBD-14189 (7) (Figure 6) that showed an $\mathrm{IC}_{50}$ of $89 \mathrm{nM}$ in a single-cycle assay (standard 6, $0.64 \mu \mathrm{M}$ ) (Table 1). However, the authors highlighted the need for further improvements concerning its ADMET (absorption, distribution, metabolism, excretion, and toxicity) properties.

Further optimization of the ADMET properties of lead compound 7 was approached by replacing the phenyl ring in the region I with a pyridine ring (Figure 6) [41], according to the benefits mentioned in the literature $[42,43,46]$. The best result was observed for NBD14270 (8) (Figure 6). Compared with analog 7, this new compound showed an increased $\mathrm{IC}_{50}$ by approximately two-fold and an improved $\mathrm{CC}_{50}$ by approximately five-fold, leading to a SI of 683 (Table 1).

Table 1. Anti-HIV-1 activity and cytotoxicity of CD4 antagonists in single-cycle (TZM-bl cells) and multicycle (MT-2 cells) assays, selectivity index (SI), and inhibition of HIV-1 RT [37,39-41,47,48].

\begin{tabular}{|c|c|c|c|c|c|c|}
\hline \multirow{2}{*}{ NBD- Analog } & \multicolumn{2}{|c|}{ TZM-bl Cells (Mean \pm SD) ${ }^{a}$} & \multicolumn{2}{|c|}{ MT-2 Cells (Mean \pm SD) a } & \multirow{2}{*}{$S_{I^{b}}^{b}$} & \multirow{2}{*}{$\begin{array}{c}\text { Inhibition of } \\
\text { HIV-1 RT } \\
\text { IC }_{50}(\mu \mathrm{M})\end{array}$} \\
\hline & $\mathrm{IC}_{50}(\mu \mathrm{M})$ & $\mathrm{CC}_{50}(\mu \mathrm{M})$ & $\mathrm{IC}_{50}(\mu \mathrm{M})$ & $\mathrm{CC}_{50}(\mu \mathrm{M})$ & & \\
\hline 1 & $\begin{array}{c}2.2 \pm 0.2^{\mathrm{d}} / \\
2.5 \pm 0.2^{\mathrm{f}}\end{array}$ & $\begin{array}{c}23.6 \pm 1.1^{\mathrm{d}} / \\
\sim 28^{\mathrm{f}}\end{array}$ & $\begin{array}{r}0.85 \pm 0.06^{\mathrm{d}} / \\
1.5 \pm 0.06^{\mathrm{f}}\end{array}$ & $\begin{array}{c}24.8 \pm 2.3^{\mathrm{d}} / \\
\sim 28^{\mathrm{f}}\end{array}$ & $10.7^{\mathrm{d} / \sim 11.2^{\mathrm{f}}}$ & $47^{\mathrm{d}} / 43.4^{\mathrm{f}}$ \\
\hline $2^{f}$ & $4.7 \pm 1.1$ & $23.7 \pm 1.1$ & $4.7 \pm 0.6$ & $>108$ & 5.04 & - \\
\hline$S-(3)$ & $2.1 \pm 0.2$ & $33.6 \pm 0.8$ & $2.7 \pm 0.33$ & $25.8 \pm 8.8$ & - & - \\
\hline$S-(4)$ & $0.59 \pm 0.06$ & $40.5 \pm 1.3$ & $0.52 \pm 0.05$ & $30.5 \pm 0.6$ & - & - \\
\hline 5 & $0.45 \pm 0.05$ & $38.8 \pm 0.8$ & $0.76 \pm 0.3$ & $38 \pm 1$ & 86.2 & 7.2 \\
\hline 6 & $0.64 \pm 0.06$ & $39.5 \pm 2.3$ & $0.96 \pm 0.1$ & $37 \pm 1.5$ & 61.7 & 8.4 \\
\hline 7 & $0.089 \pm 0.001$ & $21.9 \pm 0.5$ & $0.18 \pm 0.001$ & $22.1 \pm 1$ & 246 & $\mathrm{NT}^{\mathrm{c}}$ \\
\hline 8 & $0.16 \pm 0.004$ & $109.3 \pm 2$ & $\mathrm{NT}^{\mathrm{c}}$ & $\mathrm{NT}^{\mathrm{c}}$ & 683.1 & $\mathrm{NT}^{\mathrm{c}}$ \\
\hline 9 & $2.3 \pm 0.1$ & $145.6 \pm 7.6$ & $3.8 \pm 1.4$ & $193 \pm 6.3$ & 63.3 & $30.6 \pm 2.7$ \\
\hline 10 & $4.3 \pm 0.8$ & $142.3 \pm 2.6$ & $4.5 \pm 0.9$ & $191.5 \pm 2.6$ & 33.1 & $39.5 \pm 2.8$ \\
\hline 11 & $2.7 \pm 0.3$ & $95.8 \pm 1.4$ & $2.98 \pm 0.1$ & $180 \pm 2$ & 35.5 & $28.1 \pm 7.9$ \\
\hline $12 \mathrm{~g}$ [48] & $10.8 \pm 0.6 \mu \mathrm{M}$ & $145.9 \pm 8.9 \mu \mathrm{M}$ & $\mathrm{NT}^{\mathrm{c}}$ & $\mathrm{NT}^{\mathrm{c}}$ & - & $\mathrm{NT}^{\mathrm{c}}$ \\
\hline $13^{g}$ & $21.3 \pm 5.0 \mu \mathrm{M}$ & - & $\mathrm{NT}^{\mathrm{c}}$ & $\mathrm{NT}^{\mathrm{c}}$ & - & $\mathrm{NT}^{\mathrm{c}}$ \\
\hline Temsavir & $<1 \mathrm{nM}^{\mathrm{e}}$ & $>100^{\mathrm{e}}$ & $\mathrm{NT}^{\mathrm{c}}$ & $\mathrm{NT}^{\mathrm{c}}$ & - & $\mathrm{NT}^{\mathrm{c}}$ \\
\hline
\end{tabular}

Exploring region I by introducing bulky molecular groups such as 1,3-benzodioxolyl or its bioisostere 2,1,3-benzothiadiazole, the same group aimed to discover novel entry inhibitors of the NBD class. As a result, this change is well tolerated but does not improve antiviral activity (Table 1) [47]. The best compounds with bulky group substitutions, NBD-14110 (9), NBD-14123 (10), and NBD-14159 (11) (Figure 7), had their anti-RT activity evaluated and moderate inhibition was observed (Table 1). 


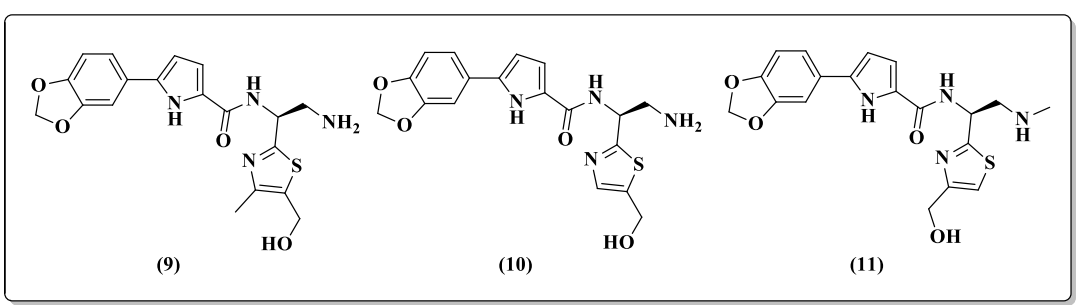

Figure 7. Chemical structures of the three best compounds synthesized by Curreli et al. [47]: 9, 10, and 11.

Compound 12 (Figure 8) was proposed based on guanidine-containing inhibitors as entry antagonists [48]. In the design of this analog, AWS-I-169 (13) [45] (Figure 8) and NBD-derivative 4 were used as prototypes. Prototype 13 interacts with the Asp368 residue of gp120, which plays a critical role in binding to Arg59 of the CD4 receptor.

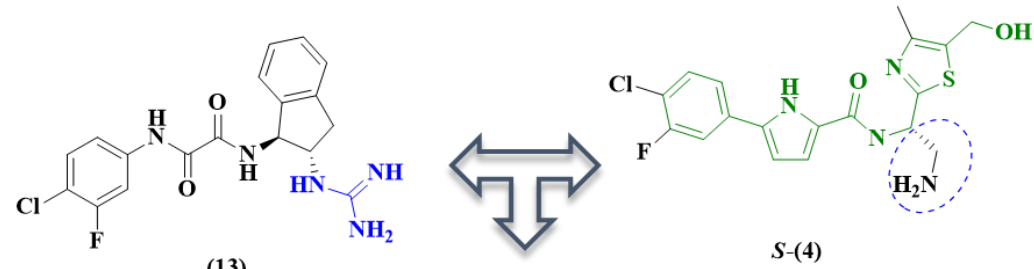

(13)

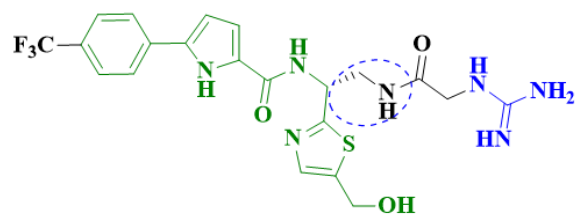

(12)

Figure 8. Design of compound 12 [45,48].

The results of the biological evaluation of derivative $\mathbf{1 2}$ showed improved antiviral activity compared to molecule 13 (compound 13, IC $5021.3 \mu \mathrm{M}$; compound 12, IC $5010.8 \mu \mathrm{M}$ ) in a single-cycle infection assay (TZM-bl cells/HIV-1 $\left.{ }_{\mathrm{HXB}-2}\right)$, but this improved activity was not observed when compared with standard NBD analog 4 ( $\left.\mathrm{IC}_{50} 0.59 \mu \mathrm{M}\right)$ [49] (Table 1). However, guanidine analog 12 showed an excellent cytotoxicity profile $\left(\mathrm{CC}_{50}\right.$ of $\left.145.9 \mu \mathrm{M}\right)$ compared with control molecule 4 ( $\mathrm{CC}_{50}$ of $\left.40.5 \mu \mathrm{M}\right)$ (Table 1) [48].

As previously described, gp41 is also responsible for the fusion process between HIV and cells [50]. This glycoprotein is considered one of the most attractive targets for developing HIV entry or fusion inhibitors because of its conserved amino acid sequence [51,52]. Based on this fact, Qiu et al. [53] used NB-64 (14) as a prototype in the design of compound 15 as a potential gp41 inhibitor (Figure 9) [54]. The data from the anti-HIV-1 assays of this derivative showed good inhibitory activity in one of the primary strains and an enfuvirtide-resistant strain (primary, $\mathrm{IC}_{50} 2.078 \mu \mathrm{M}$; enfuvirtide-resistant, $\mathrm{IC}_{50} 5.261 \mu \mathrm{M}$ ), although 15 was less active than the mentioned reference drug (primary, $\mathrm{IC}_{50} 0.062 \mu \mathrm{M}$; enfuvirtide-resistant, $\mathrm{IC}_{50}>2 \mu \mathrm{M}$ ) (Figure 9). 

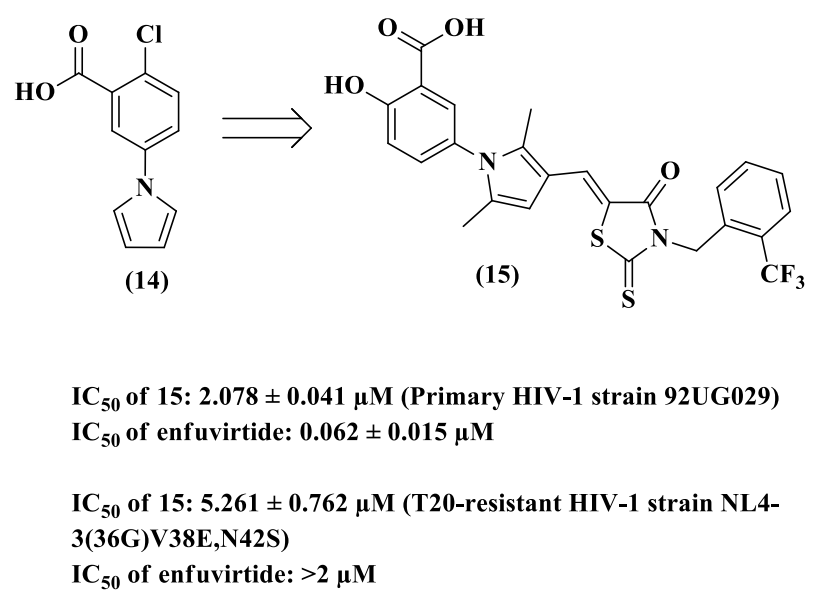

Figure 9. Chemical structures of $\mathbf{1 4}$ and $\mathbf{1 5}$ and the anti-HIV-1 profile of derivative $\mathbf{1 5}$ [53].

\section{Pyrrole-Based Anti-HIV-1 Inhibitors (Dual Inhibitors, RT Inhibitors and Replication Inhibitors)}

The therapeutic approach to treat AIDS with a drug cocktail is often compromised by low patient compliance and the risk of drug-drug interactions [55]. Therefore, the development of multitargeted molecules would be an alternative to simultaneously modulate different targets, eliminating the occurrence of drug-drug interactions and facilitating good adherence to therapy [56]. Molecules that target two enzymes are called dual inhibitors [57], and the development of these types of inhibitors is extremely interesting for AIDS management.

In this respect, some works have described the development of dual inhibitors targeting essential enzymes in the replication cycle of HIV-1, such as IN and RT [57,58]. IN is responsible for integrating the DNA of HIV-1 into the host genome. This process depends on the assistance from two $\mathrm{Mg}^{2+}$ ions that act as cofactors in the catalytic core domain (CCD) of IN. The catalytic site of the ribonuclease H domain (RNase H) of HIV-1 RT, which hydrolyzes the RNA strand of the RNA-DNA hybrid, resembles the topology found in the CCD of IN [59]. The hydrolytic process involves water molecules that act as nucleophiles and magnesium ions coordinating with the highly conserved residues of RNase H (Asp443, Asp498, Asp549, and Glu478) [60]. Due to this similarity, these two enzymes are a potential duet for the discovery of HIV-1 dual inhibitors.

Pyrrolyl scaffold is a good starting point to obtain molecules with promising anti-IN or anti-IN/RNase $\mathrm{H}$ pharmacological profiles once it has a synthetic versatility [61]. In this context, two pyrrolyl derivatives, $\mathbf{1 6}$ and 17, were developed [9,57]. Compounds $\mathbf{1 6}$ and 17 showed dual activity with micromolar IC 50 values against HIV-1 IN and RT RNase H. Notably, pyrrole 17 was a promising dual inhibitor, although it did not exhibit good potency in HIV-infected cells $\left(16, \mathrm{EC}_{50} 2 \mu \mathrm{M} ; 17, \mathrm{EC}_{50} 20 \mu \mathrm{M}\right)$ and both of them showed a $\mathrm{CC}_{50}>50 \mu \mathrm{M}$ (Figure 10). Comparing the selectivity pattern of the two compounds, 16 provides excellent and greater cell protection (SI $>25 \mu \mathrm{M})$ than $17(\mathrm{SI}>2.5 \mu \mathrm{M})$. 


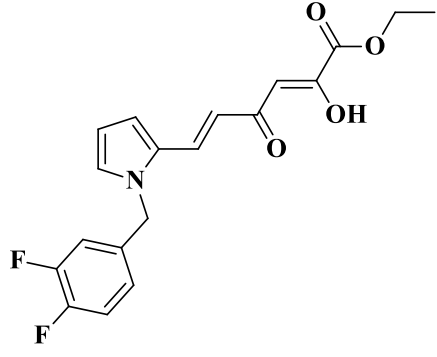

(16)

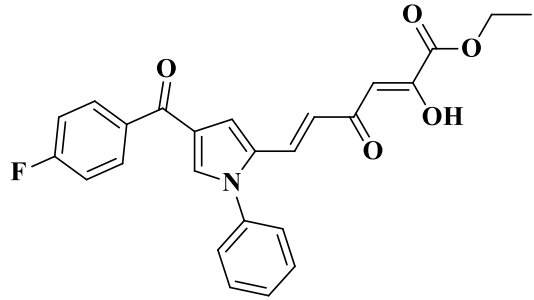

(17)

Figure 10. Chemical structures of $\mathbf{1 6}$ and $\mathbf{1 7}$ and their anti-HIV-1 profiles [57].

Intending to overcome the problems reported for diketo acid (DKA) [62] and improve selectivity for RNase H of HIV-1, Messore et al. [58] developed a library of compounds that mimicked the DKA moiety presented in dual inhibitor 18 ( $\mathrm{IC}_{50} 10 \mu \mathrm{M}$ against HIV-1 RNase H) (Figure 11) through replacement with a pyrazole ring. In this series, derivative 19 (Figure 11) was the most potent compound, showing an $\mathrm{IC}_{50}$ of $0.27 \mu \mathrm{M}$ against HIV-1 RNase H (Figure 11). Additionally, the goal of obtaining better selectivity for the RT domain versus IN was achieved, and the derivatives showed good serum stability compared to their corresponding DKA derivatives.

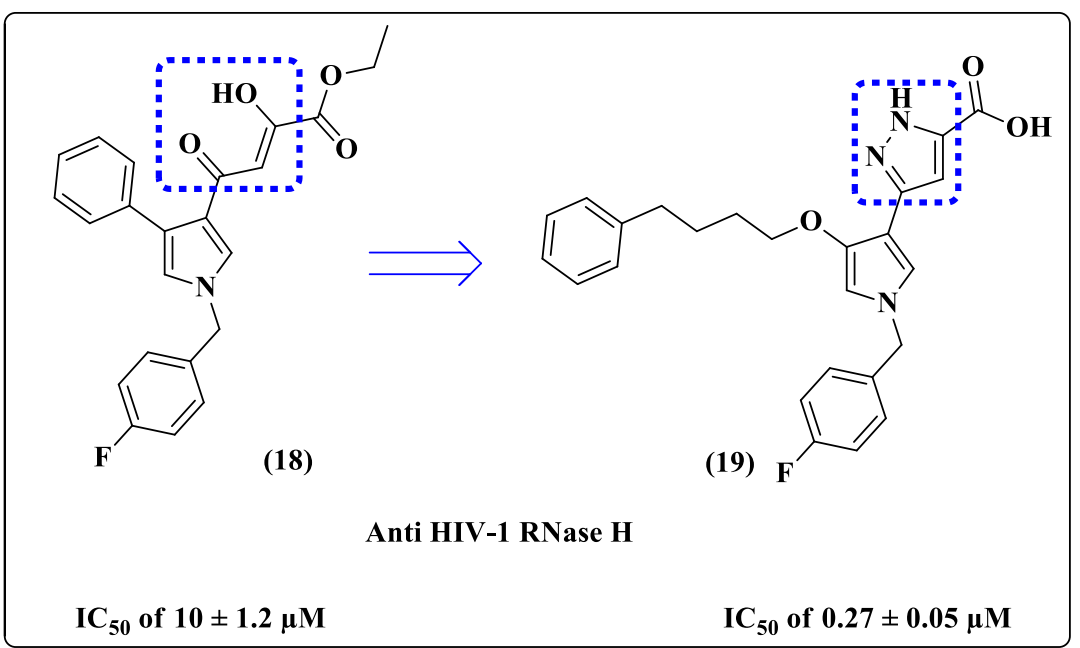

Figure 11. Chemical structures of $\mathbf{1 8}$ and $\mathbf{1 9}$ and their anti-HIV-1 RNase H activities [58].

RT plays an important role in the HIV-1 replication cycle. RNA-dependent DNA polymerase activity (RDDP), DNA-dependent DNA polymerase activity (DDDP), and RNase $\mathrm{H}$ function make RT a multifunctional enzyme. However, there are not any molecules targeting RNase H in RT approved by the FDA [63]. The DNA polymerase (pol) domain, in addition to the RNase H domain, is located at the catalytic p66 subunit of HIV-1 RT. RNase $\mathrm{H}$ domain is essential for viral genome replication by carrying out the hydrolysis of the viral RNA strand in the RNA/DNA hybrid [60], and studies show that its inhibition completely blocks viral replication [60,64-66].

RNase $\mathrm{H}$ inhibitors are a class of compounds that present critical issues that hamper drug development. First, the nucleic acid substrate (RNA/DNA hybrid) binds to p66 and interacts with both the pol and the RNase $\mathrm{H}$ active sites. Due to the reciprocal 
action between the two functions of RT, it is a challenge to achieve the selective RNase $\mathrm{H}$ inhibition over pol [67]. As previously mentioned, RT requires a coordinate binding of the RNA/DNA substrate to both pol and RNase H domains; because the majority of the binding interactions are in the pol domain, there is a low binding dependence of the substrate on the RNase H domain $[67,68]$.

In addition, RT RNase $\mathrm{H}$ belongs to the retroviral integrase superfamily, and the similarities complicate efforts toward selective inhibition of RNase H over IN. Despite the problems reported for effective inhibition of the RNase H domain of the HIV-1 RT, papers with this goal have been published [69-72].

In 2017 [73], a library of $1 H$-pyrrole-3-carbothioamide and $1 H$-pyrazole-4-carbothioamide derivatives were synthesized with the aim of obtaining molecules that are able to promote the simultaneous inhibition of all points of RT. The compounds were screened against HIV-1 (IIIB strains/MT-2 cells), and their RT-associated RNase H and RDDP inhibitory activities were measured using the methodology described by Corona et al. [74] (using prototype foamy viruses) and Meleddu et al. [75] (using an Invitrogen EnzCheck Reverse Transcriptase Assay Kit, Eugene, Or, USA), respectively.

Among the pyrrole derivatives, molecule 20 showed the best RT-associated RNase $\mathrm{H}$ inhibitory activity, with an $\mathrm{IC}_{50}$ of $6.1 \pm 1.6 \mu \mathrm{M}$. However, its $\mathrm{EC}_{50}$ value for HIV-1 inhibition activity in the cell-based assay was $>30 \mu \mathrm{M}$ (Figure 12), demonstrating its lack of ability to inhibit HIV-1 replication. In addition, all tested pyrrole derivatives were cytotoxic (Figure 12). Due to its inability to maintain cell viability, the RT-associated RDDP inhibitory activity of these pyrrole derivative was not verified. Only the most active compound, which belonged to the $1 H$-pyrazole-4-carbothioamide derivative series, was evaluated by the authors for its inhibitory potential of RT-associated RDDP [73].

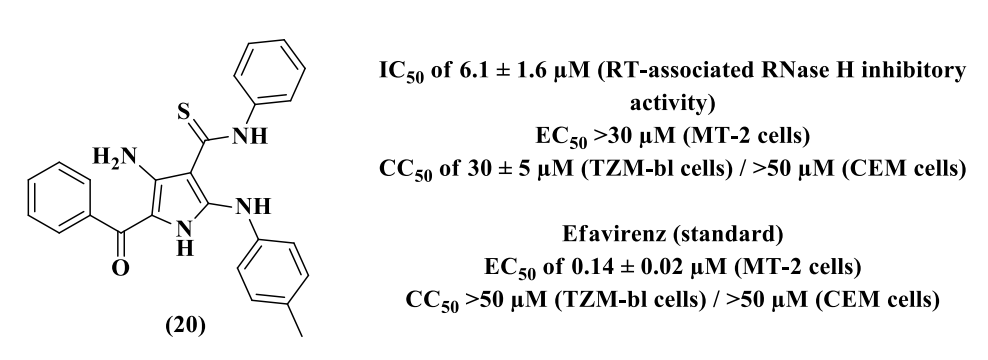

Figure 12. Chemical structure and anti-HIV-1 profile of compound 20 [73].

In search of new RT inhibitors of HIV-1, in 2019, certain copper (Cu) complexes that target this viral enzyme were reported (Figure 13) [76]. The literature described that metal chelating agents represent a strategy for the development of potential enzyme inhibitors [77-79]. Therefore, three pyrrole-copper complexes were synthesized (21-23) and found to be effective inhibitors of HIV-1 RT (Figure 13). Complex 21 had a percentage of HIV-1 RT inhibition (70.18\%) that was near that of the standard nevirapine $(100 \%)$ at a concentration of $221.69 \mu \mathrm{M}$ (Table 2). At lower concentrations, complex 22 showed better results, with $10.82 \%$ and $46.54 \%$ inhibition activity at 21.68 and $108.43 \mu \mathrm{M}$, respectively (Table 2). Regarding cytotoxicity, only complex 21 considerably decreased cell viability at all tested concentrations (Table 2).

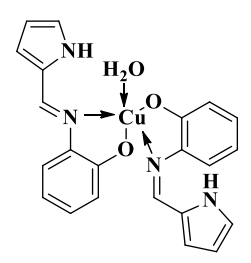

(21)

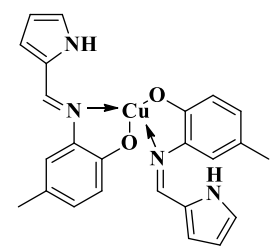

(22)

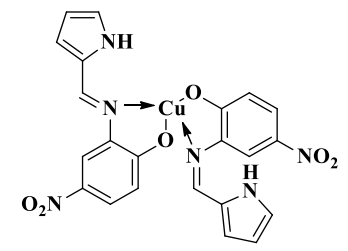

(23)

Figure 13. Chemical structures of the $\mathrm{Cu}(\mathrm{II})$ complexes of 21-23 [76]. 
Table 2. Anti-HIV-1 RT activity and cell viability of Cu(II) complexes (21-23) [76].

\begin{tabular}{|c|c|c|c|c|c|c|c|}
\hline \multirow{2}{*}{ Compound } & \multirow{2}{*}{\multicolumn{3}{|c|}{$\%$ of Inhibition (Tested Concentration) }} & \multicolumn{4}{|c|}{$\%$ of Cell Viability } \\
\hline & & & & $10 \mu \mathrm{M}$ & $50 \mu \mathrm{M}$ & $100 \mu \mathrm{M}$ & $150 \mu \mathrm{M}$ \\
\hline 21 & $\begin{array}{c}2.11 \\
(22.16 \mu \mathrm{M})\end{array}$ & $\begin{array}{c}46.54 \\
(110.84 \mu \mathrm{M})\end{array}$ & $\begin{array}{c}70.18 \\
(221.69 \mu \mathrm{M})\end{array}$ & 38 & 32 & 25 & 20 \\
\hline 22 & $\begin{array}{c}10.82 \\
(21.68 \mu \mathrm{M})\end{array}$ & $\begin{array}{c}46.54 \\
(108.43 \mu \mathrm{M})\end{array}$ & $\begin{array}{c}67.54 \\
(216.87 \mu \mathrm{M})\end{array}$ & 100 & 100 & 100 & 100 \\
\hline 23 & $\begin{array}{c}6.34 \\
(19.11 \mu \mathrm{M})\end{array}$ & $\begin{array}{c}35.17 \\
(95.59 \mu \mathrm{M})\end{array}$ & $\begin{array}{c}48.44 \\
(191.18 \mu \mathrm{M})\end{array}$ & 100 & 100 & 100 & 100 \\
\hline
\end{tabular}

Stanton and coworkers [80] identified ten novel antiretroviral compounds built with a 7-azaindole (pyrrolo[2,3-b]pyridine) core (Figure 14) by testing a library composed of 585 molecules. The antiretroviral activity of these compounds was determined in physiologically relevant primary human peripheral blood mononuclear (PBM) cells infected with HIV-1 (strain LAV-1) [81].

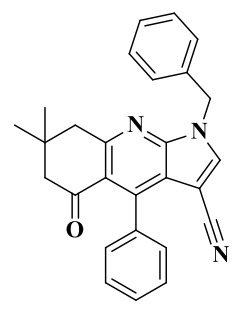

24

$\mathrm{EC}_{50}$ of $0.35 \pm 0.26 \mu \mathrm{M}$ IC $_{50}$ (RT inhibition): $0.73 \pm 0.32 \mu \mathrm{M}$

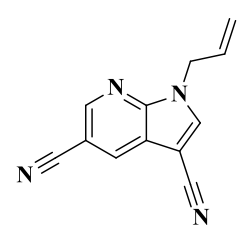

25

$\mathrm{EC}_{50}$ of $0.76 \pm 0.48 \mu \mathrm{M}$
$\mathrm{IC}_{50}(\mathrm{RT}$ inhibition $)$ : $>100 \mu \mathrm{M}$

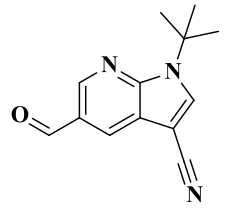

26

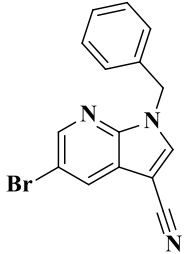

27

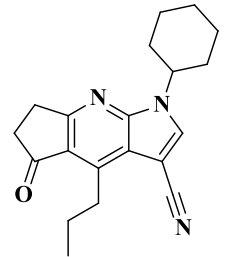

28

$$
\begin{array}{ccc}
\mathrm{EC}_{50} \text { of } 0.49 \pm 0.33 \mu \mathrm{M} & \mathrm{EC}_{50} \text { of } 0.47 \pm 0.30 \mu \mathrm{M} & \mathrm{EC}_{50} \text { of } 0.69 \pm 0.11 \mu \mathrm{M} \\
\mathrm{IC}_{50} \text { (RT inhibition): } & \mathrm{IC}_{50} \text { (RT inhibition): } & \mathrm{IC}_{50} \text { (RT inhibition): } \\
14 \pm 3.7 \mu \mathrm{M} & >100 \mu \mathrm{M} & >100 \mu \mathrm{M}
\end{array}
$$

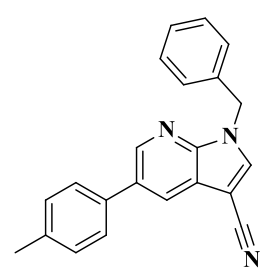

29

$\mathrm{EC}_{50}$ of $0.49 \pm 0.33 \mu \mathrm{M}$ IC $_{50}$ (RT inhibition): $>100 \mu \mathrm{M}$

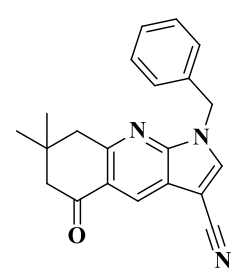

30

$$
\begin{gathered}
\mathrm{EC}_{50} \text { of } 0.91 \pm 0.52 \mu \mathrm{M} \\
\mathrm{IC}_{50}(\mathrm{RT} \text { inhibition): } \\
12 \pm 5.2 \mu \mathrm{M}
\end{gathered}
$$

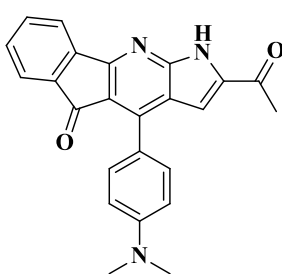

31

$$
\begin{gathered}
\mathrm{EC}_{50} \text { of } 0.93 \pm 0.10 \mu \mathrm{M} \\
\mathrm{IC}_{50}(\mathrm{RT} \text { inhibition }): \\
15 \pm 1.2 \mu \mathrm{M}
\end{gathered}
$$

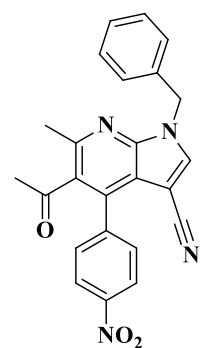

32

$$
\begin{gathered}
\mathrm{EC}_{50} \text { of } 0.19 \pm 0.05 \mu \mathrm{M} \\
\mathrm{IC}_{50}(\mathrm{RT} \text { inhibition }): \\
6.3 \pm 0.79 \mu \mathrm{M}
\end{gathered}
$$

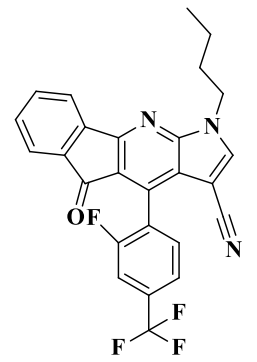

$$
\begin{gathered}
\mathrm{EC}_{50} \text { of } 0.83 \pm 0.39 \mu \mathrm{M} \\
\mathrm{IC}_{50}(\mathrm{RT} \text { inhibition }): \\
0.58 \pm 0.17 \mu \mathrm{M}
\end{gathered}
$$

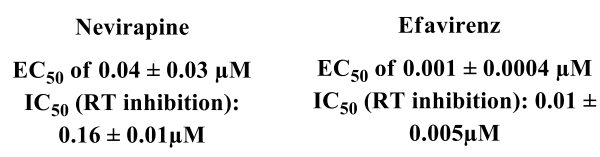

Figure 14. The ten most potent 7-azaindoles from a library of molecules investigated by Stanton and coworkers [80].

The data from Figure 14 reveal that all compounds showed submicromolar anti-HIV-1 potency. To determine the action mechanism of the most active compound 24, its ability to inhibit polymerase RT activity was measured. The $\mathrm{IC}_{50}$ detected for 24 was $0.73 \pm 0.32 \mu \mathrm{M}$ (Figure 14), and the authors concluded that this molecule acts as a non-nucleoside reverse transcriptase inhibitor (NNRTI); after increasing the nucleotide concentration, the observed 
$\mathrm{IC}_{50}$ did not decrease. In contrast, the potency verified for $\mathbf{2 4}$ was enhanced by adding natural nucleotides. Evaluation against mutant strains (K103N, Y181C, and E138K) resulted in some degree of activity; however, compound $\mathbf{2 4}$ was not able to act against the V108I mutant strain [80].

After evaluation by the free energy perturbation (FEP) method, modification of the lower phenyl ring of $\mathbf{2 4}$ was proposed in order to increase binding affinity and hence potency against RT. Therefore, compound $\mathbf{3 4}$ was synthesized and demonstrated improved potency against the HIV-1 enzyme, which was two-fold greater than that of $\mathbf{2 4}$ (IC 50 $0.36 \pm 0.01 \mu \mathrm{M})$ (Figure 15). Although more potent than 24 against wild-type RT, the new derivative 34 demonstrated some activity against the Y181C RT mutant and was inactive against RT mutant forms K103N, V108I, and E138K [80].

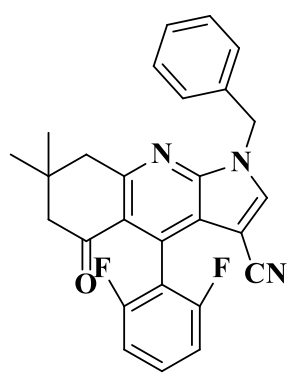

(34)

$\mathrm{IC}_{50}$ (RT inhibition): $0.36 \pm 0.01 \mu \mathrm{M}$

$\mathrm{EC}_{50}$ (PBM cells / HIV-1 strain LAV-

1): $0.46 \pm 0.23 \mu \mathrm{M}$

Figure 15. Chemical structure and anti-HIV-1 profile of compound 34 [80].

In an attempt to obtain active compounds in cells infected by HIV-1, Yonn et al. [82] synthesized new scaffolds of pyrrolo-pyridine derivatives (Figure 16). The $\mathrm{N}$-substituted pyrroles 35-37 (Figure 16) showed moderate activity against HIV-1 ( $\mathrm{EC}_{50}$ values ranging from 5.02 to $5.07 \mu \mathrm{M}$ ) when compared with the control drugs (AZT, $\mathrm{EC}_{50} 0.0063 \mu \mathrm{M}$; raltegravir, $\mathrm{EC}_{50} 0.0063 \mu \mathrm{M}$ ) (Table 3).

Recently, cyclic amides, known as lactams, coupled with pyrrole have proven to be a promising group in the search for an anti-HIV drug candidate, as demonstrated by compound 38 (Figure 16) [83]. Within a set of six compounds, 38 was the only compound active at a noncytotoxic concentration, showing an $\mathrm{EC}_{50}$ of $2.74 \pm 1.08 \mu \mathrm{M}\left(\mathrm{CC}_{50} 18.93 \pm 4.0 \mu \mathrm{M}\right)$ against HIV-1; however, 38 was inactive against replication in the HIV-2 cell line (Table 3). The docking analysis carried out with crystal structures of RT of HIV-1 and HIV-2 suggested that compound 38 was a potent HIV-1 NNRTI agent [83].

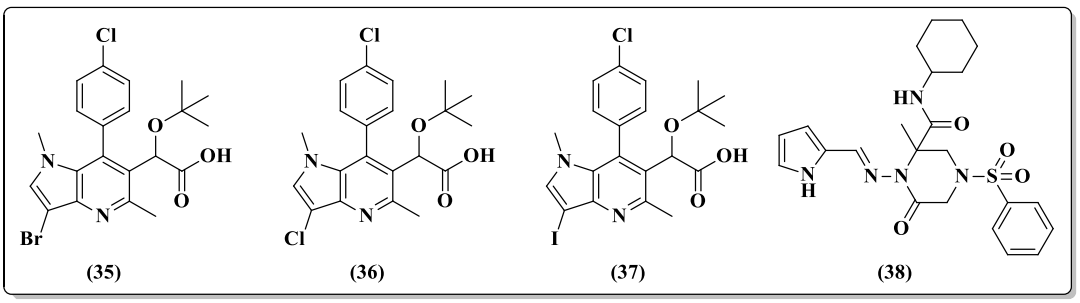

Figure 16. Chemical structure of compounds $35-\mathbf{3 8}[82,83]$. 
Table 3. Antiviral evaluation of compounds $\mathbf{3 5 - 3 8}$ in MT-4 cells [82,83].

\begin{tabular}{|c|c|c|c|c|c|}
\hline \multirow{2}{*}{ Compound } & \multicolumn{3}{|c|}{ Antiviral Activity $\left(\mathrm{EC}_{50}\right)(\mu \mathrm{M})$} & \multicolumn{2}{|c|}{$\mathrm{CC}_{50}(\mu \mathrm{M})^{\mathrm{b}}$} \\
\hline & HTLV-III $_{B}{ }^{\text {a }}$ & HIV-1, IIIB ${ }^{\text {b }}$ & HIV-2, ROD ${ }^{b}$ & HIV-1, IIIB ${ }^{\text {b }}$ & HIV-2, ROD ${ }^{b}$ \\
\hline 35 & 5.02 & $\mathrm{NT}^{\mathrm{c}}$ & $\mathrm{NT}^{\mathrm{c}}$ & $\mathrm{NT}^{\mathrm{c}}$ & $\mathrm{NT}^{\mathrm{c}}$ \\
\hline 36 & 5.03 & $\mathrm{NT}^{\mathrm{c}}$ & $\mathrm{NT}^{\mathrm{c}}$ & $\mathrm{NT}^{\mathrm{c}}$ & $\mathrm{NT}^{\mathrm{c}}$ \\
\hline 37 & 5.07 & $\mathrm{NT}^{\mathrm{c}}$ & $\mathrm{NT}^{\mathrm{c}}$ & $\mathrm{NT}^{\mathrm{c}}$ & $\mathrm{NT}^{\mathrm{c}}$ \\
\hline 38 & $\mathrm{NT}^{\mathrm{c}}$ & $2.74 \pm 1.08$ & $>17.13$ & $18.93 \pm 4.0$ & $>18.95$ \\
\hline AZT & 0.0063 & $\mathrm{NT}^{\mathrm{c}}$ & $\mathrm{NT}^{\mathrm{c}}$ & $\mathrm{NT}^{\mathrm{c}}$ & $\mathrm{NT}^{\mathrm{c}}$ \\
\hline Raltegravir & 0.0063 & $\mathrm{NT}^{\mathrm{c}}$ & $\mathrm{NT}^{\mathrm{c}}$ & $\mathrm{NT}^{\mathrm{c}}$ & $\mathrm{NT}^{\mathrm{c}}$ \\
\hline Efavirenz & $\mathrm{NT}^{\mathrm{c}}$ & 0.00441 & $\mathrm{NT}^{\mathrm{c}}$ & $>6.327$ & $\mathrm{NT}^{\mathrm{c}}$ \\
\hline Nevirapine & $\mathrm{NT}^{\mathrm{c}}$ & 0.198 & $\mathrm{NT}^{\mathrm{c}}$ & $>14.02$ & $\mathrm{NT}^{\mathrm{c}}$ \\
\hline
\end{tabular}

As shown, pyrrole-based anti-HIV compounds are promising therapeutic agents for the treatment of AIDS. In this work, we attempted to review the literature involving the development of pyrrole analogs as anti-HIV agents in the time period between 2015 and 2020.

\section{Concluding Remarks and Future Directions}

AIDS therapy faces a series of drawbacks, mainly because its treatment is based on a cocktail that is difficult for patients to adhere to. Moreover, other significant problems exist, such as long-term toxicity, the emergence of drug-resistant viral strains, and drugdrug interactions. In this context, there is a continuous need to identify new anti-HIV agents based on several chemical groups, including nitrogenated heterocycles such as pyrroles. Among the compounds with potent antiretroviral activity, designs based on the pyrrole scaffold is significant. This was confirmed with fostemsavir, which is the first antiretroviral drug used against HIV-1, and exhibits a pyrrole ring in its structure, showing the importance of exploring this nucleus.

It is possible to predict that pyrrole-based antiretrovirals can be further exploited because they may provide compounds with high activity in the micromolar or nanomolar range. In addition, it was observed that targeting the Asp368 residue of gp120 may possibly lead to the design of molecules that are attractive and innovative pyrrole drugs as entry inhibitors. Another promising approach using this ring is in the field of multitargeted molecules focused on the enzymes IN and RT, because these enzymes share similar topological features in their catalytic sites. As a result, certain compounds containing pyrrole rings with interesting in vitro and ADMET profiles are potential candidates for new antiretroviral drugs.

In summary, this review analyzed the progress between 2015 and 2020 regarding the antiretroviral activity of molecules containing a pyrrole ring, which is considered a privileged scaffold for drug discovery.

Author Contributions: Conceptualization, M.d.C.A.D.B., D.I.L.F.M., L.V.B.H., M.M.B. and N.B. Resources, M.d.C.A.D.B. and D.I.L.F.M. Writing-original draft preparation, M.d.C.A.D.B., D.I.L.F.M. and L.V.B.H. Writing-review and editing, L.V.B.H., M.M.B. and N.B. Supervision, M.M.B. and N.B. All authors have read and agreed to the published version of the manuscript.

Funding: The authors thank the National Council of R\&D of Brazil (CNPq) for fellowship and grants to NB (306193/2018-3 and 404054/2018-8). They also thank the Foundations for Research of the State of Rio de Janeiro (FAPERJ) for the fellowships granted ("Cientista do Nosso Estado") to NB (E-26/202.805/2017). This work was financed in part by the Coordenação de Aperfeiçoamento de Pessoal de Nivel Superior-Brazil (CAPES) to MCADB.

Institutional Review Board Statement: Not applicable. 
Informed Consent Statement: Not applicable.

Data Availability Statement: Data sharing not applicable.

Conflicts of Interest: The authors declare no conflict of interest.

\section{References}

1. Available online: https://www.who.int/news-room/fact-sheets/detail/hiv-aids (accessed on 8 March 2021).

2. Available online: https:/ / unaids.org.br/estatisticas/\#: \{\}:text=38\%20milh $\%$ C3 $\%$ B5es $\% 20 \% 5 B 31 \% 2 C 6 \% 20 \mathrm{milh} \% \mathrm{C} 3 \% \mathrm{~B} 5 \mathrm{es}, \mathrm{at} \%$ C3\%A9\%20o\%20fim\%20de\%202019 (accessed on 8 March 2021).

3. Becerra, J.C.; Bildstein, L.S.; Gach, J.S. Recent Insights into the HIV/AIDS Pandemic. Microb. Cell 2016, 3, 450-474. [CrossRef] [PubMed]

4. Moranguinho, I.; Valente, S.T. Block-and-Lock: New Horizons for a Cure for HIV-1. Viruses 2020, 12, 1443. [CrossRef]

5. Rossi, E.; Meuser, M.; Cunanan, C.; Cocklin, S. Structure, Function, and Interactions of the HIV-1 Capsid Protein. Life 2021, 11, 100. [CrossRef] [PubMed]

6. Himmel, D.M.; Arnold, E. Non-Nucleoside Reverse Transcriptase Inhibitors Join Forces with Integrase Inhibitors to Combat HIV. Pharmacy 2020, 13, 122. [CrossRef]

7. Larijani, M.S.; Ramezani, A.; Sadat, S.M. Updated Studies on the Development of HIV Therapeutic Vaccine. Curr. HIV Res. 2019, 17, 75-84. [CrossRef]

8. Patel, R.V.; Park, S.W. Pyrroloaryls and pyrroloheteroaryls: Inhibitors of the HIV fusion/attachment, reverse transcriptase and integrase. Bioorg. Med. Chem. 2015, 23, 5247-5263. [CrossRef]

9. Costi, R.; Métifiot, M.; Esposito, F.; Crucitti, G.C.; Pescatori, L.; Messore, A.; Scipione, L.; Tortorella, S.; Zinzula, L.; Novellino, E.; et al. 6-(1-Benzyl-1H-pyrrol-2-yl)-2,4-dioxo-5-hexenoic Acids as Dual Inhibitors of Recombinant HIV-1 Integrase and Ribonuclease H, Synthesized by a Parallel Synthesis Approach. J. Med. Chem. 2013, 56, 8588-8598. [CrossRef] [PubMed]

10. Petri, G.L.; Spanò, V.; Spatola, R.; Holl, R.; Raimondi, M.V.; Barraja, P.; Montalbano, A. Bioactive pyrrole-based compounds with target selectivity. Eur. J. Med. Chem. 2020, 208, 112783. [CrossRef]

11. Walsh, C.T.; Garneau-Tsodikova, S.; Howard-Jones, A.R. Biological formation of pyrroles: Nature's logic and enzymatic machinery. Nat. Prod. Rep. 2006, 23, 517-531. [CrossRef]

12. Katritzky, A.R.; Rees, C.W.; Scriven, E.F.V. Comprehensive Heterocyclic Chemistry II: A Review of the Literature 1982-1995, 2nd ed.; Pergamon: São Paulo, Brazil, 1996.

13. Sruthi, P.R.; Sankar, P.U.; Saranya, T.V.; Anas, S. Facile Synthesis of Dihydroquinolines via Palladium Catalyzed Sequential Amination and Cyclisation of Morita-Baylis-Hillman Alcohols. ChemistrySelect 2020, 5, 13598-13602. [CrossRef]

14. Iqbal, S.; Rasheed, H.; Awan, R.J.; Awan, R.J.; Mukhtar, A.; Moloney, M.G. Recent Advances in the Synthesis of Pyrroles. Curr. Org. Chem. 2020, 24, 1196-1229. [CrossRef]

15. Bhardwaj, V.; Gumber, D.; Abbot, V.; Dhiman, S.; Sharma, P. Pyrrole: A resourceful small molecule in key medicinal heteroaromatics. RSC Adv. 2015, 5, 15233-15266. [CrossRef]

16. Gholap, S.S. Pyrrole: An emerging scaffold for construction of valuable therapeutic agents. Eur. J. Med. Chem. 2016, 110, 13-31. [CrossRef]

17. Kaur, R.; Rani, V.; Abbot, V.; Kapoor, Y.; Konar, D.; Kumar, K. Recent synthetic and medicinal perspectives of pyrroles: An overview. J. Pharm. Chem. Chem. Sci. 2017, 1, 17-32.

18. Ahmad, S.; Alam, O.; Naim, M.J.; Shaquiquzzaman, M.; Alam, M.M.; Iqbal, M. Pyrrole: An insight into recent pharmacological advances with structure activity relationship. Eur. J. Med. Chem. 2018, 157, 527-561. [CrossRef] [PubMed]

19. Huang, Y.-M.; Alharbi, N.S.; Sun, B.; Shantharam, C.; Rakesh, K.; Qin, H.-L. Synthetic routes and structure-activity relationships (SAR) of anti-HIV agents: A key review. Eur. J. Med. Chem. 2019, 181, 111566. [CrossRef]

20. Motati, D.R.; Uredi, D.; Watkins, E.B. The Discovery and Development of Oxalamide and Pyrrole Small Molecule Inhibitors of gp120 and HIV Entry-A Review. Curr. Top. Med. Chem. 2019, 19, 1650-1675. [CrossRef]

21. Sing, T.; Chou, K.-C.; Sirois, S. HIV-1 gp120 V3 Loop for Structure-Based Drug Design. Curr. Protein Pept. Sci. $2005,6,413-422$. [CrossRef]

22. Tintori, C.; Selvaraj, M.; Badia, R.; Clotet, B.; Esté, J.A.; Botta, M. Computational Studies Identifying Entry Inhibitor Scaffolds Targeting the Phe 43 Cavity of HIV-1 gp120. ChemMedChem 2013, 8, 475-483. [CrossRef]

23. Esté, J.A.; Telenti, A. HIV entry inhibitors. Lancet 2007, 370, 81-88. [CrossRef]

24. Gulick, R.M. Investigational Antiretroviral Drugs: What is Coming Down the Pipeline. Top. Antivir. Med. 2018, $25,127-132$. [PubMed]

25. Zhang, Y.; Chapman, J.H.; Ulcay, A.; Sutton, R.E. Neutralization Synergy between HIV-1 Attachment Inhibitor Fostemsavir and Anti-CD4 Binding Site Broadly Neutralizing Antibodies against HIV. J. Virol. 2019, 93, e01446-18. [CrossRef] [PubMed]

26. Available online: https://www.fda.gov/news-events/press-announcements/fda-approves-new-hiv-treatment-patients-limitedtreatment-options (accessed on 10 March 2021).

27. Available online: https://www.ema.europa.eu/en/medicines/human/EPAR/rukobia (accessed on 10 March 2021).

28. Markham, A. Fostemsavir: First Approval. Drugs 2020, 80, 1-6. [CrossRef] [PubMed] 
29. Guo, Q.; Ho, H.-T.; Dicker, I.; Fan, L.; Zhou, N.; Friborg, J.; Wang, T.; McAuliffe, B.V.; Wang, H.-G.H.; Rose, R.E.; et al. Biochemical and Genetic Characterizations of a Novel Human Immunodeficiency Virus Type 1 Inhibitor That Blocks gp120-CD4 Interactions. J. Virol. 2003, 77, 10528-10536. [CrossRef] [PubMed]

30. Pancera, M.; Lai, Y.-T.; Bylund, T.; Druz, A.; Narpala, S.; O’Dell, S.; Schön, A.; Bailer, R.T.; Chuang, G.-Y.; Geng, H.; et al. Crystal structures of trimeric HIV envelope with entry inhibitors BMS-378806 and BMS-626529. Nat. Chem. Biol. 2017, 13, 1115-1122. [CrossRef]

31. Langley, D.R.; Kimura, S.R.; Sivaprakasam, P.; Zhou, N.; Dicker, I.; McAuliffe, B.; Wang, T.; Kadow, J.F.; Meanwell, N.; Krystal, M. Homology models of the HIV-1 attachment inhibitor BMS-626529 bound to gp120 suggest a unique mechanism of action. Proteins Struct. Funct. Bioinform. 2015, 83, 331-350. [CrossRef]

32. Li, Z.; Zhou, N.; Sun, Y.; Ray, N.; Lataillade, M.; Hanna, G.; Krystal, M. Activity of the HIV-1 Attachment Inhibitor BMS-626529, the Active Component of the Prodrug BMS-663068, against CD4-Independent Viruses and HIV-1 Envelopes Resistant to other Entry Inhibitors. Antimicrob. Agents Chemother. 2013, 57, 4172-4180. [CrossRef]

33. Nowicka-Sans, B.; Gong, Y.-F.; McAuliffe, B.; Dicker, I.; Ho, H.-T.; Zhou, N.; Eggers, B.; Lin, P.-F.; Ray, N.; Wind-Rotolo, M.; et al. In Vitro Antiviral Characteristics of HIV-1 Attachment Inhibitor BMS-626529, the Active Component of the Prodrug BMS-663068. Antimicrob. Agents Chemother. 2012, 56, 3498-3507. [CrossRef]

34. Ray, N.; Hwang, C.; Healy, M.; Whitcomb, J.; Lataillade, M.; Wind-Rotolo, M.; Krystal, M.; Hanna, G. Prediction of Virological Response and Assessment of Resistance Emergence to the HIV-1 Attachment Inhibitor BMS-626529 During 8-Day Monotherapy with Its Prodrug BMS-663068. JAIDS J. Acquir. Immune Defic. Syndr. 2013, 64, 7-15. [CrossRef]

35. Zhou, N.; Nowicka-Sans, B.; McAuliffe, B.; Ray, N.; Eggers, B.; Fang, H.; Fan, L.; Healy, M.; Langley, D.R.; Hwang, C.; et al. Genotypic correlates of susceptibility to HIV-1 attachment inhibitor BMS-626529, the active agent of the prodrug BMS-663068. J. Antimicrob. Chemother. 2013, 69, 573-581. [CrossRef]

36. Seval, N.; Frank, C.; Kozal, M. Fostemsavir for the treatment of HIV. Expert Rev. Anti-Infect. Ther. 2021, 19, 961-966. [CrossRef]

37. Curreli, F.; Kwon, Y.D.; Zhang, H.; Scacalossi, D.; Belov, D.S.; Tikhonov, A.A.; Andreev, I.; Altieri, A.; Kurkin, A.V.; Kwong, P.D.; et al. Structure-Based Design of a Small Molecule CD4-Antagonist with Broad Spectrum Anti-HIV-1 Activity. J. Med. Chem. 2015, 58, 6909-6927. [CrossRef]

38. Curreli, F.; Belov, D.S.; Ramesh, R.R.; Patel, N.; Altieri, A.; Kurkin, A.V.; Debnath, A.K. Design, synthesis and evaluation of small molecule CD4-mimics as entry inhibitors possessing broad spectrum anti-HIV-1 activity. Bioorg. Med. Chem. 2016, 24, 5988-6003. [CrossRef]

39. Curreli, F.; Kwon, Y.D.; Belov, D.S.; Ramesh, R.R.; Kurkin, A.V.; Altieri, A.; Kwong, P.D.; Debnath, A.K. Synthesis, Antiviral Potency, in Vitro ADMET, and X-ray Structure of Potent CD4 Mimics as Entry Inhibitors that Target the Phe43 Cavity of HIV-1 gp120. J. Med. Chem. 2017, 60, 3124-3153. [CrossRef] [PubMed]

40. Curreli, F.; Belov, D.S.; Kwon, Y.D.; Ramesh, R.; Furimsky, A.M.; O’Loughlin, K.; Byrge, P.C.; Iyer, L.V.; Mirsalis, J.C.; Kurkin, A.; et al. Structure-based lead optimization to improve antiviral potency and ADMET properties of phenyl-1H-pyrrole-carboxamide entry inhibitors targeted to HIV-1 gp120. Eur. J. Med. Chem. 2018, 154, 367-391. [CrossRef]

41. Curreli, F.; Ahmed, S.; Victor, S.M.B.; Iusupov, I.R.; Belov, D.S.; Markov, P.O.; Kurkin, A.V.; Altieri, A.; Debnath, A.K. Preclinical Optimization of gp120 Entry Antagonists as anti-HIV-1 Agents with Improved Cytotoxicity and ADME Properties through Rational Design, Synthesis, and Antiviral Evaluation. J. Med. Chem. 2020, 63, 1724-1749. [CrossRef]

42. Hamada, Y. Role of Pyridines in Medicinal Chemistry and Design of BACE1 Inhibitors Possessing a Pyridine Scaffold. Pyridine 2018, 9-26. [CrossRef]

43. Wang, T.; Yin, Z.; Zhang, Z.; Bender, J.A.; Yang, Z.; Johnson, G.; Zadjura, L.M.; D’Arienzo, C.J.; Parker, D.D.; Gesenberg, C.; et al. Inhibitors of Human Immunodeficiency Virus Type 1 (HIV-1) Attachment. 5. An Evolution from Indole to Azaindoles Leading to the Discovery of 1-(4-Benzoylpiperazin-1-yl)-2-(4,7-dimethoxy-1H-pyrrolo[2,3-c]pyridin-3-yl)ethane-1,2-dione (BMS-488043), a Drug Candidate that Demonstrates Antiviral Activity in HIV-1-Infected Subjects. J. Med. Chem. 2009, 52, 7778-7787. [CrossRef] [PubMed]

44. Kwon, Y.D.; LaLonde, J.M.; Yang, Y.; Elban, M.A.; Sugawara, A.; Courter, J.R.; Jones, D.M.; Smith, A.B.; Debnath, A.K.; Kwong, P.D. Crystal Structures of HIV-1 gp120 Envelope Glycoprotein in Complex with NBD Analogues That Target the CD4-Binding Site. PLoS ONE 2014, 9, e85940. [CrossRef]

45. LaLonde, J.M.; Kwon, Y.D.; Jones, D.M.; Sun, A.W.; Courter, J.R.; Soeta, T.; Kobayashi, T.; Princiotto, A.M.; Wu, X.; Schön, A.; et al. Structure-Based Design, Synthesis, and Characterization of Dual Hotspot Small-Molecule HIV-1 Entry Inhibitors. J. Med. Chem. 2012, 55, 4382-4396. [CrossRef]

46. Hartz, R.A.; Ahuja, V.T.; Zhuo, X.; Mattson, R.J.; Denhart, D.J.; Deskus, J.A.; Vrudhula, V.M.; Pan, S.; Ditta, J.L.; Shu, Y.-Z.; et al. A Strategy to Minimize Reactive Metabolite Formation: Discovery of (S)-4-(1-Cyclopropyl-2-methoxyethyl)-6-[6-(difluoromethoxy)2,5-dimethylpyridin-3-ylamino]-5-oxo-4,5-dihydropyrazine-2-carbonitrile as a Potent, Orally Bioavailable Corticotropin-Releasing Factor-1 Receptor Antagonist. J. Med. Chem. 2009, 52, 7653-7668. [CrossRef]

47. Curreli, F.; Belov, D.S.; Ahmed, S.; Ramesh, R.R.; Kurkin, A.V.; Altieri, A.; Debnath, A.K. Synthesis, Antiviral Activity, and Structure-Activity Relationship of 1,3-Benzodioxolyl Pyrrole-Based Entry Inhibitors Targeting the Phe43 Cavity in HIV-1 gp120. ChemMedChem 2018, 13, 2332-2348. [CrossRef] [PubMed]

48. Belov, D.S.; Curreli, F.; Kurkin, A.V.; Altieri, A.; Debnath, A.K. Guanidine-Containing Phenyl-Pyrrole Compounds as Probes for Generating HIV Entry Inhibitors Targeted to gp120. ChemistrySelect 2018, 3, 6450-6453. [CrossRef] 
49. Ohashi, N.; Harada, S.; Mizuguchi, T.; Irahara, Y.; Yamada, Y.; Kotani, M.; Nomura, W.; Matsushita, S.; Yoshimura, K.; Tamamura, H. Small-Molecule CD4 Mimics Containing Mono-cyclohexyl Moieties as HIV Entry Inhibitors. ChemMedChem 2016, 11, 940-946. [CrossRef] [PubMed]

50. Zhu, P.; Liu, J.; Bess, J., Jr.; Chertova, E.; Lifson, J.D.; Grisé, H.; Ofek, G.A.; Taylor, K.A.; Roux, K.H. Distribution and threedimensional structure of AIDS virus envelope spikes. Nature 2006, 441, 847-852. [CrossRef] [PubMed]

51. Lu, L.; Yu, F.; Cai, L.; Debnath, A.K.; Jiang, S. Development of Small-molecule HIV Entry Inhibitors Specifically Targeting gp120 or gp41. Curr. Top. Med. Chem. 2015, 16, 1074-1090. [CrossRef]

52. Yi, H.A.; Fochtman, B.C.; Rizzo, R.C.; Jacobs, A. Inhibition of HIV Entry by Targeting the Envelope Transmembrane Subunit gp41. Curr. HIV Res. 2016, 14, 283-294. [CrossRef]

53. Qiu, J.; Liang, T.; Wu, J.; Yu, F.; He, X.; Tian, Y.; Xie, L.; Jiang, S.; Liu, S.; Li, L. N-Substituted Pyrrole Derivative 12m Inhibits HIV-1 Entry by Targeting Gp41 of HIV-1 Envelope Glycoprotein. Front. Pharmacol. 2019, 10, 859. [CrossRef]

54. Jiang, S.; Lu, H.; Liu, S.; Zhao, Q.; He, Y.; Debnath, A.K. N-Substituted Pyrrole Derivatives as Novel Human Immunodeficiency Virus Type 1 Entry Inhibitors That Interfere with the gp41 Six-Helix Bundle Formation and Block Virus Fusion. Antimicrob. Agents Chemother. 2004, 48, 4349-4359. [CrossRef]

55. Prati, F.; Uliassi, E.; Bolognesi, M.L. Two diseases, one approach: Multitarget drug discovery in Alzheimer's and neglected tropical diseases. MedChemComm 2014, 5, 853-861. [CrossRef]

56. Talevi, A. Multi-target pharmacology: Possibilities and limitations of the "skeleton key approach" from a medicinal chemist perspective. Front. Pharmacol. 2015, 6, 205. [CrossRef]

57. Crucitti, G.C.; Métifiot, M.; Pescatori, L.; Messore, A.; Madia, V.N.; Pupo, G.; Saccoliti, F.; Scipione, L.; Tortorella, S.; Esposito, F.; et al. Structure-Activity Relationship of Pyrrolyl Diketo Acid Derivatives as Dual Inhibitors of HIV-1 Integrase and Reverse Transcriptase Ribonuclease H Domain. J. Med. Chem. 2015, 58, 1915-1928. [CrossRef]

58. Messore, A.; Corona, A.; Madia, V.N.; Saccoliti, F.; Tudino, V.; De Leo, A.; Scipione, L.; De Vita, D.; Amendola, G.; Di Maro, S.; et al. Pyrrolyl Pyrazoles as Non-Diketo Acid Inhibitors of the HIV-1 Ribonuclease H Function of Reverse Transcriptase. ACS Med. Chem. Lett. 2020, 11, 798-805. [CrossRef] [PubMed]

59. Yang, F.; Zheng, G.; Fu, T.; Li, X.; Tu, G.; Li, Y.H.; Yao, X.; Xue, W.; Zhu, F. Prediction of the binding mode and resistance profile for a dual-target pyrrolyl diketo acid scaffold against HIV-1 integrase and reverse-transcriptase-associated ribonuclease $\mathrm{H}$. Phys. Chem. Chem. Phys. 2018, 20, 23873-23884. [CrossRef]

60. Poongavanam, V.; Corona, A.; Steinmann, C.; Scipione, L.; Grandi, N.; Pandolfi, F.; Di Santo, R.; Costi, R.; Esposito, F.; Tramontano, E.; et al. Structure-guided approach identifies a novel class of HIV-1 ribonuclease H inhibitors: Binding mode insights through magnesium complexation and site-directed mutagenesis studies. MedChemComm 2018, 9, 562-575. [CrossRef]

61. Corona, A.; Di Leva, F.S.; Rigogliuso, G.; Pescatori, L.; Madia, V.N.; Subra, F.; Delelis, O.; Esposito, F.; Cadeddu, M.; Costi, R.; et al. New insights into the interaction between pyrrolyl diketoacids and HIV-1 integrase active site and comparison with RNase H. Antivir. Res. 2016, 134, 236-243. [CrossRef] [PubMed]

62. Krieger, I.V.; Freundlich, J.S.; Gawandi, V.B.; Roberts, J.P.; Gawandi, V.B.; Sun, Q.; Owen, J.L.; Fraile, M.T.; Huss, S.I.; Lavandera, J.-L.; et al. Structure-Guided Discovery of Phenyl-diketo Acids as Potent Inhibitors of M. tuberculosis Malate Synthase. Chem. Biol. 2012, 19, 1556-1567. [CrossRef] [PubMed]

63. Menéndez-Arias, L.; Sebastián-Martín, A.; Alvarez, M. Viral reverse transcriptases. Virus Res. 2017, 234, 153-176. [CrossRef]

64. Corona, A.; Di Leva, F.S.; Thierry, S.; Pescatori, L.; Crucitti, G.C.; Subra, F.; Delelis, O.; Esposito, F.; Rigogliuso, G.; Costi, R.; et al. Identification of Highly Conserved Residues Involved in Inhibition of HIV-1 RNase H Function by Diketo Acid Derivatives. Antimicrob. Agents Chemother. 2014, 58, 6101-6110. [CrossRef]

65. Tramontano, E.; Esposito, F.; Badas, R.; Di Santo, R.; Costi, R.; La Colla, P. 6-[1-(4-Fluorophenyl)methyl-1H-pyrrol-2-yl)]-2,4-dioxo5 -hexenoic acid ethyl ester a novel diketo acid derivative which selectively inhibits the HIV-1 viral replication in cell culture and the ribonuclease $\mathrm{H}$ activity in vitro. Antivir. Res. 2005, 65, 117-124. [CrossRef]

66. Massari, S.; Corona, A.; Distinto, S.; Desantis, J.; Caredda, A.; Sabatini, S.; Manfroni, G.; Felicetti, T.; Cecchetti, V.; Pannecouque, C.; et al. From cycloheptathiophene-3-carboxamide to oxazinone-based derivatives as allosteric HIV-1 ribonuclease H inhibitors. J. Enzym. Inhib. Med. Chem. 2019, 34, 55-74. [CrossRef]

67. Wang, L.; Sarafianos, S.G.; Wang, Z. Cutting into the Substrate Dominance: Pharmacophore and Structure-Based Approaches toward Inhibiting Human Immunodeficiency Virus Reverse Transcriptase-Associated Ribonuclease H. Acc. Chem. Res. 2020, 53, 218-230. [CrossRef]

68. Beilhartz, G.L.; Ngure, M.; Johns, B.A.; DeAnda, F.; Gerondelis, P.; Götte, M. Inhibition of the Ribonuclease H Activity of HIV-1 Reverse Transcriptase by GSK5750 Correlates with Slow Enzyme-Inhibitor Dissociation. J. Biol. Chem. 2014, 289 , 16270-16277. [CrossRef]

69. Himmel, D.M.; Maegley, K.A.; Pauly, T.A.; Bauman, J.D.; Das, K.; Dharia, C.; Clark, A.D.; Ryan, K.; Hickey, M.J.; Love, R.A.; et al. Structure of HIV-1 Reverse Transcriptase with the Inhibitor $\beta$-Thujaplicinol Bound at the RNase H Active Site. Structure 2009, 17, 1625-1635. [CrossRef] [PubMed]

70. Billamboz, M.; Bailly, F.; Lion, C.; Touati, N.; Vezin, H.; Calmels, C.; Andréola, M.-L.; Christ, F.; Debyser, Z.; Cotelle, P. Magnesium Chelating 2-Hydroxyisoquinoline-1,3(2H,4H)-diones, as Inhibitors of HIV-1 Integrase and/or the HIV-1 Reverse Transcriptase Ribonuclease H Domain: Discovery of a Novel Selective Inhibitor of the Ribonuclease H Function. J. Med. Chem. 2011, 54, 1812-1824. [CrossRef] [PubMed] 
71. Himmel, D.M.; Myshakina, N.S.; Ilina, T.; Van Ry, A.; Ho, W.C.; Parniak, M.A.; Arnold, E. Structure of a Dihydroxycoumarin Active-Site Inhibitor in Complex with the RNase H Domain of HIV-1 Reverse Transcriptase and Structure-Activity Analysis of Inhibitor Analogs. J. Mol. Biol. 2014, 426, 2617-2631. [CrossRef]

72. Velthuisen, E.J.; Johns, B.A.; Gerondelis, P.; Chen, Y.; Li, M.; Mou, K.; Zhang, W.; Seal, J.W.; Hightower, K.E.; Miranda, S.R.; et al. Pyridopyrimidinone inhibitors of HIV-1 RNase H. Eur. J. Med. Chem. 2014, 83, 609-616. [CrossRef] [PubMed]

73. Corona, A.; Onnis, V.; Deplano, A.; Bianco, G.; Demurtas, M.; Distinto, S.; Cheng, Y.-C.; Alcaro, S.; Esposito, F.; Tramontano, E. Design, synthesis and antiviral evaluation of novel heteroarylcarbothioamide derivatives as dual inhibitors of HIV-1 reverse transcriptase-associated RNase H and RDDP functions. Pathog. Dis. 2017, 75, ftx078. [CrossRef] [PubMed]

74. Corona, A.; Schneider, A.; Schweimer, K.; Rösch, P.; Wöhrl, B.M.; Tramontano, E. Inhibition of Foamy Virus Reverse Transcriptase by Human Immunodeficiency Virus Type 1 RNase H Inhibitors. Antimicrob. Agents Chemother. 2014, 58, 4086-4093. [CrossRef]

75. Meleddu, R.; Cannas, V.; Distinto, S.; Sarais, G.; DEL Vecchio, C.; Esposito, F.; Bianco, G.; Corona, A.; Cottiglia, F.; Alcaro, S.; et al. Design, Synthesis, and Biological Evaluation of 1,3-Diarylpropenones as Dual Inhibitors of HIV-1 Reverse Transcriptase. ChemMedChem 2014, 9, 1869-1879. [CrossRef]

76. Shanty, A.; Raghu, K.; Mohanan, P. Synthesis, characterization: Spectral and theoretical, molecular docking and in vitro studies of copper complexes with HIV RT enzyme. J. Mol. Struct. 2019, 1197, 154-163. [CrossRef]

77. Rogolino, D.; Carcelli, M.; Sechi, M.; Neamati, N. Viral enzymes containing magnesium: Metal binding as a successful strategy in drug design. Coord. Chem. Rev. 2012, 256, 3063-3086. [CrossRef]

78. Barry, N.P.E.; Sadler, P.J. Exploration of the medical periodic table: Towards new targets. Chem. Commun. 2013, 49, 5106-5131. [CrossRef] [PubMed]

79. Cao, L.; Song, W.; Clercq, E.; Zhan, P.; Liu, X. Recent Progress in the Research of Small Molecule HIV-1 RNase H Inhibitors. Curr. Med. Chem. 2014, 21, 1956-1967. [CrossRef]

80. Stanton, R.A.; Lu, X.; Detorio, M.; Montero, C.; Hammond, E.T.; Ehteshami, M.; Domaoal, R.A.; Nettles, J.; Feraud, M.; Schinazi, R.F. Discovery, characterization, and lead optimization of 7-azaindole non-nucleoside HIV-1 reverse transcriptase inhibitors. Bioorg. Med. Chem. Lett. 2016, 26, 4101-4105. [CrossRef] [PubMed]

81. Schinazi, R.F.; Sommadossi, J.P.; Saalmann, V.; Cannon, D.L.; Xie, M.Y.; Hart, G.C.; Smith, G.A.; Hahn, E.F. Activities of 3'azido-3'-deoxythymidine nucleotide dimers in primary lymphocytes infected with human immunodeficiency virus type 1. Antimicrob. Agents Chemother. 1990, 34, 1061-1067. [CrossRef] [PubMed]

82. Yoon, H.-A.; Nam, H.-J.; Kim, U.-I.; Kim, K.; Kim, B.J. Synthesis and Antiviral Activity of Some 1H-Pyrrolo[3,2-b]pyridin-6yl)acetic Acid Derivatives. Asian J. Chem. 2017, 29, 1199-1205. [CrossRef]

83. Jassem, A.M.; Dhumad, A.M. Synthesis, Antimicrobial Activity, Anti-HIV Activity, and Molecular Docking of Novel 5-, 6- and 7-Membered Ring (1 H -Pyrrol-2-yl)aminolactams. ChemistrySelect 2021, 6, 2641-2647. [CrossRef] 